\title{
MICROBIAL POPULATIONS DURING COMPOSTING PROCESS OF ORGANIC FRACTION OF MUNICIPAL SOLID WASTE
}

\author{
R. REBOLLIDO ${ }^{1 *}-$ J. MARTÍNEZ $^{2}-$ Y. AGUILERA ${ }^{1}-$ K. MELCHOR $^{1}-$ I. KOERNER $^{3}-$ \\ R. STEGMANN ${ }^{3}$
}

\author{
${ }^{1}$ Higher Institute of Technologies and Applied Sciences. Havana, Cuba. InSTEC. Ave. Salvador \\ Allende y Luaces. Quinta de los Molinos. Plaza de la Revolución. Ciudad de la Habana. CP \\ 10600, AP 6163, Cuba. \\ (phone:537-8782811 ; fax: 537-2041188) \\ ${ }^{2}$ University of Havana. Faculty of Biology. Havana, Cuba. \\ ${ }^{3}$ Hamburg University of Technology, Institute of WasteResources Management. Germany \\ *Corresponding author: \\ e-mail: rocio@instec.cu
}

(Received $1^{\text {st }}$ February 2007; accepted $24^{\text {th }}$ March 2008)

\begin{abstract}
Composting is one of the more economical and environmentally safe methods of recycling waste generated by the consumer society. Due to the complexity of substrates and intermediate products, microbial diversity and the succession of populations is a prerequisite to ensure complete biodegradation. In the present work, we studied the succession of microbial populations during composting process of organic fraction of Municipal Solid Waste and some physical and chemical parameters were followed during process, moisture content was maintained at $50-60 \%$ and temperature monitored daily, in order to study the effects of important environmental factors on microbial communities. The results showed that the substrate was colonized in major proportion by bacteria (44.6\%), actinomycetes (32.3\%) and in lower number by fungi $(23.1 \%)$, mainly represent by the following dominant genera: Bacillus, Streptomyces, Actinomyces, Pseudomonas and Azospirillum. The Multiple Regression Analysis, reveal that the environmental parameter that major influence made on the microbial groups mentioned was the temperature.
\end{abstract}

Keywords: compost, microbial communities, bacteria, actinomycetes, fungi

\section{Introduction}

Composting is an aerobic process by which organic materials are degraded through the activities of successive groups of microorganisms; it is an environmentally sound way to reduce organic wastes and produce organic fertiliser or soil conditioner (Gajdos, 1992). Composting of the organic fractions of municipal solid waste (MSW) is therefore expected to increase substantially in many conuntries, parly due to legislative changes (Barth and Kroeger, 1998).

Although composting is a microbiological process, little is known about microorganisms involved and their activities during specific phases of the composting process. Definig the diversity and structure of microbial communities of compost through their constituent populations has been of considerable interest to compost researchers in order to address basic ecological questions such as how similar are microbial communities in mature compost that were made from different feedstocks and using different composting methods (Tiquia and Michel, 2002). Different microbial communities predominate during the various composting phases (mesophilic and thermophilic), each of which being adapted to a particular environment. The 
composition of the microbial communities during composting is determined by many factors (temperature, $\mathrm{pH}$, water content, $\mathrm{C} / \mathrm{N}$, etc). In adition under aerobic conditions, temperature is the major selective factor for populations and determines the rate of metabolic activities.

Despite the use of growth requiring culturing techniques is often disputed, while the culture-independent molecular screening techniques will definitely detect numerous unique microorganisms, a few references clearly indicate that culturing studies still deliver non-overlaping information, consequently none of the two approaches can claim to be superior to the other yet (Brambilla et al., 2001; Gurther et al., 2001; Dees and Ghiorse, 2001).

The aim of this study was reveal the succession of microbial populations during a whole composting process and the influence of some physical and chemical parameters under microbial concentrations. The composition of microbial communities was investigated by conventional cultured techniques.

\section{Materials and methods}

\section{Compost site and sampling}

Organic fraction of Municipal Solid Waste (MSW) compost was sampled in March 2005 at a small scale composting plant in Landfill "Calle 100" (Havana City). The waste was processed in open windrows of about $15 \mathrm{~m}$ length, $2 \mathrm{~m}$ of width and a height of $1 \mathrm{~m}$. The windrows were turned two times per month with a compost turner. Samples were taken daily the first four days and weekly during rest of the time (26 weeks) at a deep of $15 \mathrm{~cm}$ below the surface, according to Olynciw (2002). From each pile three samples were taken from separated positions (about $5 \mathrm{~m}$ distance), each of these samples was composed of three subsamples that were bulked after sieving ( $<8 \mathrm{~mm}$ mesh). Samples were transporter to the laboratory rapidly and all the trials were made in the same day.

\section{Physical and chemical parameters measured}

Temperature of the piles was monitored daily during the process using composting thermometers inserted at different heights in the piles. The water content was determined by drying of samples at $105^{\circ} \mathrm{C}$ for $48 \mathrm{~h}$. For $\mathrm{pH}$ and electric conductivity measurement, a solid-liquid extraction was carried out: compost samples were diluted 1:10 in distilled water, placed in a shaker for $24 \mathrm{~h}$ and finally a vacuum filtration was made.

\section{Isolation of microbial cultures from compost}

The compost sample $(5 \mathrm{~g})$ was diluted in $45 \mathrm{~mL}$ of buffer solution $(0.06 \mathrm{M}$ $\left.\mathrm{Na}_{2} \mathrm{HPO}_{4} / \mathrm{NaH}_{2} \mathrm{PO}_{4}\right)(1 / 9 \mathrm{v} / \mathrm{v})$, $\mathrm{pH}$ 7.6. Decimal serials dilutions $\left(10^{-1}\right.$ to $\left.10-^{10}\right)$ were made and inoculated aseptically in Petri dishes $(10 \mu \mathrm{L}$ for plate) with different culture media: Potato Dextrose Agar (PDA), Nutrient Agar (NA) and Starch Ammoniacal Agar (SAA); in order to facilitate the growth of fungi, bacteria and actinomycetes respectively. Petri dishes were incubated at $30^{\circ} \mathrm{C}$ (mesophilic microorganisms) and $50^{\circ} \mathrm{C}$ (termophilies) for $72 \mathrm{~h}(\mathrm{PDA}), 37^{\circ} \mathrm{C}$ or $50^{\circ} \mathrm{C}$ for $24 \mathrm{~h}$ (NA) and $37^{\circ} \mathrm{C}$ or $55^{\circ} \mathrm{C}$ for $120 \mathrm{~h}$ (SAA), according to the phase were the isolation was carried out. After incubation isolated colonies of bacteria, fungi and actinomycetes were selected. The evaluation of 
cellular concentration in a compost samples was determined by plate counting of serials dilutions according to equation 1 :

$$
\mathrm{CFU} / \mathrm{g}=\text { Colonies Numbers } \bullet \text { dilution } \bullet 100
$$

\section{Characterisation of isolates}

Conventional morphological criteria and biochemical test were made to pure culture of bacteria and actinomycetes according to Bergey's Manual (1994). Identification of fungal species and genera were carried out according to Raper and Fenell (1965); Ellis, (1971, 1976) and Bissett (1991). All the isolated were phenotipically characterized by the API 20B test System.

\section{Statistical analysis}

The influence of physical and chemical parameters [temperature, $\mathrm{pH}$, water content and electric conductivity (EC)] on the microbial concentration was tested statistically by means of the analysis of variance (ANOVA) and multiple regression analysis using the Stargraphics Plus v.3.0 program.

\section{Results}

The following groups of microorganisms were found in organic waste compost microbial complex: Gram-negative aerobes of genera Pseudomonas, Azotobacter, Azospirillum Gram-positive aerobes of genera Micrococcus, Gram-negative microorganisms included spore forming bacteria of the genera Bacillus, microorganisms of actinomycetes line (Gram-positive bacteria) Streptomyces, Actinomyces groups. Among the microscopic fungi that were also found; Trichoderma, Alternaria, Penicillium, Ulocladium and Aspergillus. Microbial populations densities were usually high $\left(10^{8}-10^{11} \mathrm{CFUg}^{-1}\right.$ of compost). Fig. 1 shows the composition of the microbiota in MSW compost, as well the frequency of appearance of the microbial genera.

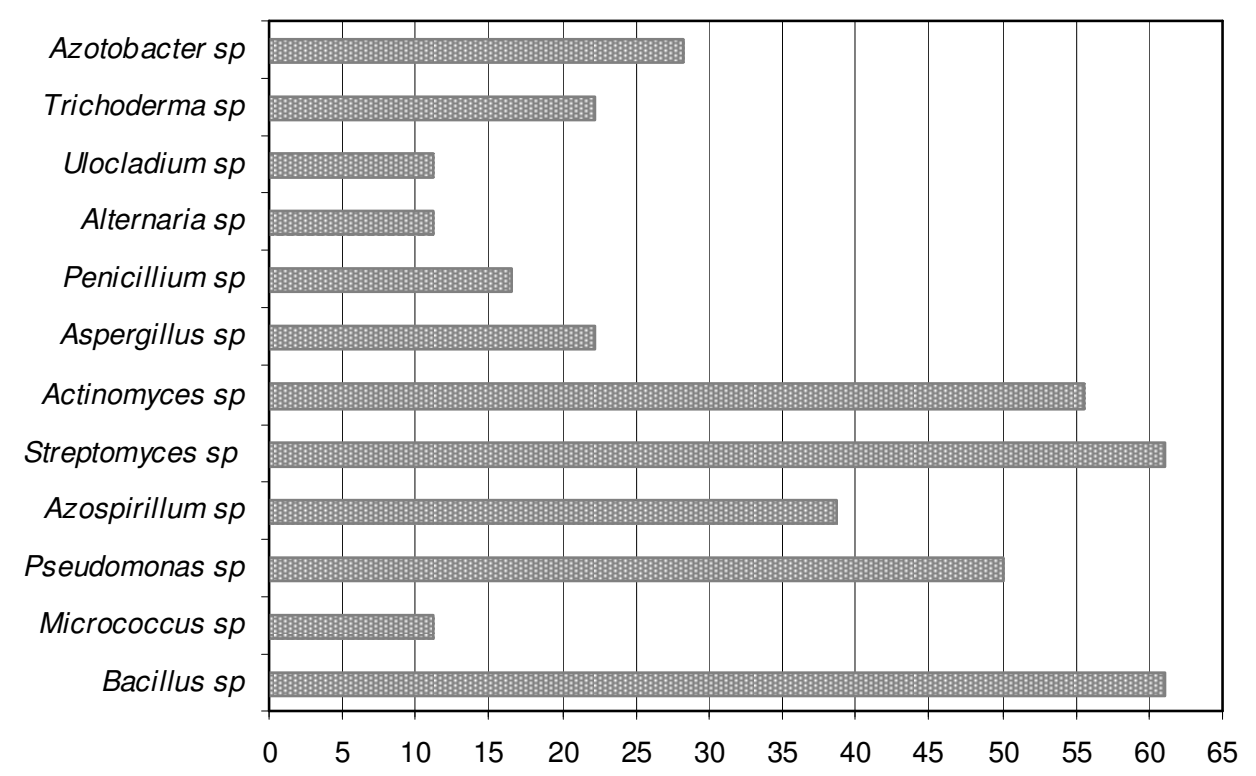

Figure 1. Composition of the microbiota (\%) in municipal solid waste compost. 
In the analysis of the data on microbial diversity we considered as dominating those species of microorganisms whose relative abundance excceded or reached about $30 \%$ (Dobrovol'skaya et al., 1997). MSW community had two genera of dominant microorganisms Bacillus and Streptomyces (61.1\%), followed by Actinomyces (55.5\%), Pseudomonas (50\%), Azospirillum (38.8\%). Many of those genera are also members of soil microbiota; these results are not surprising, due to the similarity between compost and a soil in good conditions as to physical-chemical characteristics. The fungal specie Ulocladium atrum Preuss, is consider as a new report for MSW compost.

The substrate was colonized in major proportion by bacteria that represents $(44.6 \%)$, followed by actinomycetes $(32.3 \%)$ and in lower number by fungi $(23.1 \%)$. Bacteria are nutritionally also the most diverse group of compost microorganisms, using a broad range of enzymes to chemically degrade a variety of organic materials, as a result, numbers of bacteria are usually much higher than number of others microorganisms, e.g. fungi (if total numbers are comparable at all). Consequently, bacteria are responsible for the most of initial decomposition and heat generation in compost, provide the major growth requirements are met. The succession of microbial populations (bacteria, fungi and actinomycetes) during compost process is shown in Fig. 2.
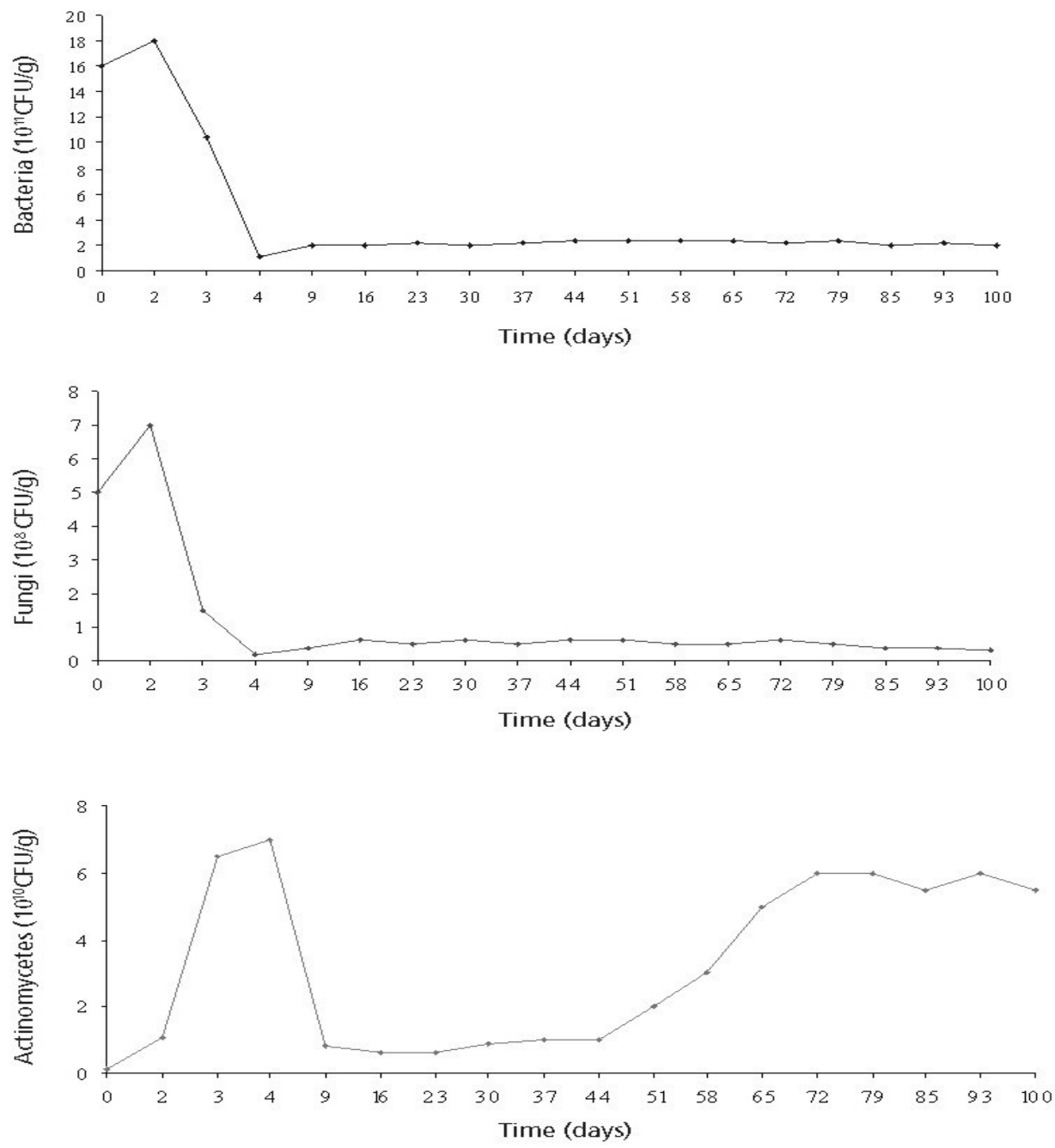

Figure 2. Succession of microbial populations (bacteria, actinomycetes and fungi) during a whole composting process. 
Table 1 shows the values of physical and chemical parameters measured during the whole composting process. After data processing, statistical analysis demonstrated that temperature and $\mathrm{pH}$ were significantly at $\mathrm{p}<0.01$ (bacteria, fungi and actinomycetes), water content and electric conductivity were significantly at $\mathrm{p}<0.01$ only for fungal concentrations. The equations obtained were:

Bacteria $=0.497793 * \mathrm{pH}-0.0542572 *$ Temperature $*$

Actinomycetes $=-9.78774+1.56072 * \mathrm{pH}-0.0300973 *$ Temperature $*$

Fungi $=0.593048 * \mathrm{EC}+0.0256965 * \mathrm{H}_{2} \mathrm{Ocontent}-0.22765 * \mathrm{pH}-0.0136299 * \mathrm{Temp}$ (Eq.4)

Table 1. Physical and chemical parameters measured during MSW compost on days 0, 16, $30,44,58,72,85,100$.

\begin{tabular}{c|ccccccccc}
\hline Parameters & \multicolumn{10}{|c}{ Days } \\
\cline { 2 - 10 } Temperature $\left({ }^{\circ} \mathrm{C}\right)$ & $\mathbf{0}$ & $\mathbf{4}$ & $\mathbf{1 6}$ & $\mathbf{3 0}$ & $\mathbf{4 4}$ & $\mathbf{5 8}$ & $\mathbf{7 2}$ & $\mathbf{8 5}$ & $\mathbf{1 0 0}$ \\
$\mathrm{pH}$ & 24.1 & 60.3 & 32.5 & 29 & 27.2 & 28.2 & 26.8 & 25 & 23 \\
Electric conductivity $(\mathrm{mS} / \mathrm{cm})$ & 6.8 & 8.1 & 7.3 & 7.4 & 7.25 & 7.35 & 7.45 & 7.3 & 7.5 \\
Water Content $(\%)$ & 1.21 & 1.94 & 2.06 & 1.99 & 2.1 & 1.98 & 1.78 & 1.8 & 1.96 \\
& 63.9 & 50.8 & 59.1 & 55.3 & 51.4 & 54.6 & 59.8 & 55.9 & 49.6 \\
\hline
\end{tabular}

\section{Discussion}

During the composting process, the $\mathrm{pH}$ dropped from 8.1 to 7.3 , wich may be due to the ammonification and mineralisation of organci matter by the activities of micoorganisms as found by Wong et al. (2001). The decline of water content in some cases may be explained by microbial heat generation causing enhanced desiccation (Tiquia and Tam, 2000). The Multiple Regression Analysis, reveal that the parameter that major influence made on the microbial groups mentioned was the temperature (data not shown). In this experiment, the decline of temperature indicated that the compost had gone through the thermofilic stage and approached maturity., the microbial biomass also decreased with composting age, except in the case of actinomycetes.

The increase in bacterial and fungal concentrations evidenced during the mesophilic phase, was influenced fundamentally by temperature and $\mathrm{pH}$. During initial phase of the composting process the substrate is at ambient temperature, the $\mathrm{pH}$ is usually slightly acidic and are available easily organic compounds. Mesophilic fungi and bacteria are the dominant active degraders of fresh organic waste materials. Food waste containing vegetable residues often have a low initial $\mathrm{pH}$ (4.5-5), which stimulates the proliferation of fungi (Ryckeboer et al., 2003). The high surface/volume ratio of bacteria allows a rapid transfer of soluble substrate into a cell. Nevertheless, actinomycetes are commonly identified as one the main groups responsible for organic matter conversion during latter stages of composting and thermophilic phase (temperatures of 45 to $55^{\circ} \mathrm{C}$ ) according to Chopra (2004) and Velasco et al. (2004). High temperatures support degradation of recalcitrant organics such as lignocellulose and elimination of pathogenic and allergenic microorganisms. Actinomycetes compete with others organisms for nutrients and can inhibit microbial growth due to the production of antibiotics, lytic enzymes or even by parasitism. They play an important role in the 
degrading natural polymers process and colonize organic materials after bacteria and fungi have consumed easily degrade fractions (maduration phase); their enzymes enable them to degrade tough debris such as: woody stems, bark or newspaper. The interaction between various functional groups of microorganisms depends on nutrient resources and the biochemical mechanisms of organic and inorganic matter transformation changes (Insam et al., 2002). Microorganisms with high hydrolyzing activities prevailed, they are spore forming (Bacillus), mycelial (Streptomyces, Actinomyces and fungi) and cellulolytic (essentials fungi). The bacteria Pseudomonas, Azotobacter, Azospirillum use simple organic material formed at hydrolysis and fermentation in aerobic conditions. The redistribution of populations to a degree of dominant and the developmentof stable forms of microorganisms preserve the diversity of species in the structure of community and signify structural-funtional changes.

The genera Micrococcus, Bacillus, Streptomyces, Actinomyces, Azotobacter, Aspergillus, Penicillium and Trichoderma have been abovementioned by Ryckeboer et al. (2003); Velarde et al. (2004) and Martínez (2004) in different compost studies. The genera Ulocladium sp. has been reported by Seck and Kilbertus (1996) in peanut shells. Several of these genera may find application as potential biocontrol agents are used in the agriculture as fitopathogens biocontrollers agents or as stimulants of the vegetable growth.

Futher non-cultivation studies will be necessary, in order to understand better the behavior of microorganisms and to compare both results. Futhermore, it will be interesting to study some mechanisms of degradation at biochemical levels by the isolated strains.

Acknowledgements. The authors thank Biology Faculty of Havana University for providing laboratory space. We also thank to professor Heribert Insam of the Innsbruck University, Institute of Microbiology, Austria for his valuable book.

\section{REFERENCES}

[1] Barth J., Kroeger B. (1998): Composting progress in Europe. - BioCycle April.1998: 6568.

[2] Bergey's Manual of Systematic Bacteriology. (1994): $9^{\text {th }}$ Edition. Williams Wilkins, Baltimore, London.

[3] Bissett, J. (1991): A revision of the genus Trichoderma. IV. Additional notes on section Longibrachiatum. - Canada. J. Bot. 69:2418-2420

[4] Brambilla E., Hippe H., Hagelstein A., Tindall B., Stackebrandt E. (2001): 16S rDNA diversity of cultured and uncultured prokaryotes of a mat sample frorm Lake Fryxell, McMurdo Dry Valleys, Antartica. - Extremophiles 5: 23-33.

[5] Chopra S. (2004): Quantification and compostition audit of waste generated at the early morning market in Vientiane, Lao PDR. - M.Eng. Thesis. Department of Civil Engenieering. University of Toronto.

[6] Dees P.M., Ghiorse W.C. (2001): Microbial diversity in hot synthetic compost as revealed by PCR-amplified rRNA sequences from cultivated isolates and extracted DNA. - FEMS Microbial. Ecol. 35:207-216.

[7] Dobrovol'skaya Tg., Chernov Iyu., Zvyagintsev DG. (1997: Characterizing the strcuture of bacterial communities. - Microbiologia. 66: 408-414. 
[8] Ellis M. B. (1971): Demateaceous Hyphomycetes. Principal Mycologist. - Common Wealth Mycological Institute. Kew, Surrey, England.

[9] Ellis M. B. (1976): More Dematiaceous Hyphomycetes. Mycological Institute. Kew, Surrey, England.

[10] Gajdos R. (1992): The use of organic waste materials as organic fertilisers-recycling of plant nutrients. - Acta Hortic 302: 325-331.

[11] Gurther C., Heyrman J., Pinar G., Lubitz W., Swings J., Rollete S. (2000): Comparative analyses of the bacterial diversity on two different biodeteriorated wall paintings by DGGE and 16S rDNA sequence análisis. - Int. Biodeterioration Biodegrad. 46: 229-239.

[12] Insam H., Riddech N., Klammer S. (2002): Microbiology of composting. - Springer edtion. pp 99-108.

[13] Martínez G. (2004): Evolución temporal del madurado de alperujo procedente de almazara. - Escuela Técnica Superior de Ingenieros Agrónomos y Montes. Universidad de Córdoba.

[14] Olynciw E. (2002): Cornell Composting. Compost Microorganisms. - Science \& Engineering. Institute of Environmental Sciences.

[15] Raper K.B., Fenell D.S. (1965): The Genus Aspergillus. - Ed. The Williams y Wilkins Co., Baltimore, USA.

[16] Ryckeboer J., Megaert J., Coosemans J., Deprins K., Swings J. (2003): Microbiological aspects of biowaste during composting in a monitored compost bin. - J. Appl. Microbiol., 94 (1): 127-137.

[17] Seck M.A., Kilbertus G. (1996): Fresh and composted pea-nuts shells microflora. - In: de Bertoldi M., Sequi P., Lemmes B., Papi T., Eds, The Science of Composting. Part 1, Chapman \& Hall, London, pp. 1322-1330.

[18] Tiquia SM., Michel FC Jr. (2002): Bacterial Diversity in Livestock manure compost as characterized by terminal restriction fragment length polymorphisms (T-RFLP) of PCRamplified 16S rRNA gene sequences.

[19] Tiquia SM., Tam NFY. (2000): Co-composting of spent pig litter ans sludge with torced aeration. - Biores Technol. 72: 1-7.

[20] Velasco J., Figueroa B., Ferrera R., Trinidad A., Gallegos J. (2004): $\mathrm{CO}_{2}$ y dinámica de poblaciones microbianas en composta de estiércol y paja con aireación.

[21] Velarde E., de León Ortiz M., Cuellar I., Villegas R. (2004): Producción y aplicación de compost. - INICA.

[22] Wong JWC., Mak KF., Chan NW., Lam A., Fang M., Zhou LX., Wu QT., Liao XD. (2001): Co-compost of soybean residues and leaves in Hong Kong. - Biores Technol. 76: 99-106. 